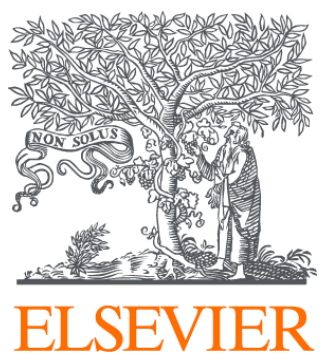

Since January 2020 Elsevier has created a COVID-19 resource centre with free information in English and Mandarin on the novel coronavirus COVID-

19. The COVID-19 resource centre is hosted on Elsevier Connect, the company's public news and information website.

Elsevier hereby grants permission to make all its COVID-19-related research that is available on the COVID-19 resource centre - including this research content - immediately available in PubMed Central and other publicly funded repositories, such as the WHO COVID database with rights for unrestricted research re-use and analyses in any form or by any means with acknowledgement of the original source. These permissions are granted for free by Elsevier for as long as the COVID-19 resource centre remains active. 
This is clearly important since about $50 \%$ of sera from patients with a surviving graft will inhibit appropriate M.L.C. cultures. ${ }^{4}$ Alternatively these sera may have reactivity directed against determinants on $B$ cells which are considered to be analogous to the la antigen system in the mouse. ${ }^{5}$

Department of Hamatology,

Charing Cross Hospital

London W6 8RF

G. D. Pegrum

C. A. Evans

\section{TRISOMY-20 SYNDROME IN MAN}

SIR,-Dr Pallister and his colleagues (Feb. 21, p. 431) have reported a possible new syndrome due to trisomy-20. Cytogenetic analysis of lymphocytes showed an apparently normal karyotype but a proportion of the fibroblasts in each of two cases contained an extra chromosome 20. The patients are, therefore, apparently chromosome mosaics.

While the striking resemblance between these two patients could indicate that this conclusion is reasonable, we would point out that cytogenetically abnormal fibroblasts have been reported at a high frequency at early passage levels in lines of fibroblasts grown from the skin of normal healthy adults. ${ }^{6}$ Harnden et al. ${ }^{7}$ studied 59 lines from adults of which 16 were found to contain clones of cytogenetically abnormal cells. Abnormalities were usually structural rearrangements but extra chromosomes were also found, and in two lines all of the cells seemed to have an abnormal karyotype. Where duplicate lines from the same tissue samples were studied, common abnormalities were not found.

We concluded that these cells either arose at a very early stage in culture or were present in vivo. Caution should therefore be observed when associating clinical abnormalities with the finding of abnormal chromosomes in fibroblast cultures alone. Where possible, duplicate lines should be studied to avoid possible anomalous results. It is not clear whether Pallister et al. analysed duplicate lines.

The possibility that the chromosomally abnormal cells in cultures from normal individuals are present in vivo and have a detectable phenotypic effect needs further investigation.

Department of Cancer Studies,

Medical School,

P. A. BENN

Birminghain B15 2TJ

D. G. HARNDEN

\section{FATAL EMBOLISM DESPITE LOW-DOSE HEPARIN}

SIR,-We report a case of death from massive pulmonary embolism in a patient, apparently cured of severe tetanus, who had received prophylactic low-dose heparin.

The patient was a 53-year-old obese female with severe tetanus (injury to first symptom 5 days, first symptom to first spasm 2 days). In view of the high mortality from pulmonary embolism in severe tetanus treated with intermittent-positivepressure ventilation, we routinely anticoagulate after tracheostomy; but to avoid the bleeding problems associated with conventional anticoagulation in tracheostomised patients we decided to administer low-dose heparin. The patient was given 5000 units of heparin 12-hourly subcutaneously.

After 5 weeks, when all signs of tetanus had apparently disappeared, the patient was weaned off the ventilator, but the heparin was continued in the same dose. Clinical signs of a deep-vein thrombosis developed in the leg a week later, and the patient was immediately given 10000 units of heparin intravenously, with the intention of repeating the dose 6-hourly. However, within a few hours she died from a massive pulmonary embolism.

4. Singal, D. P., Youngla1, E. V., Naipaul, N. Tissue Antigens, 1975, 5, 19.

5. Jones, E. A., Goodfellow, P. N., Bodmer, J. G., Bodmer, W. F. Nature, 1975 , 256,650 .

6. Littlefield, L. G., Mailhes, J. B. Am. F. hum. Genet. 1975, 27, 190.

7 Harnden, D. G., Benn, P. A., Oxford, J M., Taylor, A. M. R., Webb, T. P. Somat. Cell Genet. 1976, 2, 11
We recommend that conventional anticoagulation should be used in severe tetanus.

Norfolk and Norwich Hospital,

JENNIFER JENKINS

Norwich NR1 3SR

PhILIP KEEP

\section{ENDEMIC (BAL.KAN) NEPHROPATHY}

SIR,-Apostolov et al. ${ }^{1}$ have described evidence of a viral ætiology in endemic (Balkan) nephropathy. Our data (preliminary results were published three years ago $^{2}$ ) accord with some of the findings of Apostolov et al. We also found granular deposits of IgG in glomeruli by direct immunofluorescent examination. In addition, in a few patients in the early stage of the disease, before terminal renal insufficiency, we observed intense deposits of IgG and C3 on tubular basement membranes (see figure). The deposits were finely granular. We could not

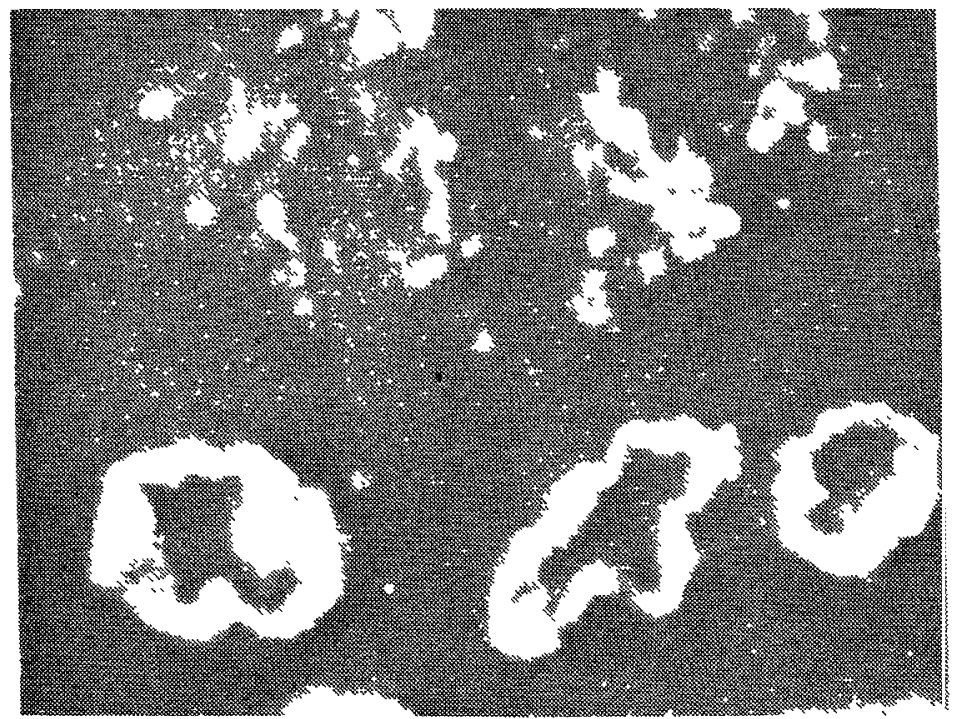

Intense deposits on tubular basement membranes and less intense in glomeruli.

(Fluorescein-labelled anti-Igb; $\times 185$.)

demonstrate circulating antibodies to tubular basement membranes in indirect immunofluorescence using patient's sera and normal human kidney as the target organ. We measured the concentration of $\mathrm{C} 3$ in 38 sera from patients with Balkan nephropathy (at different stages of the disease) and $50 \%$ had significantly low C3 concentrations.

These results do indicate that endemic nephropathy is an immune-complex-type nephritis. The antigen component in such complexes may be viral in the course of slow coronavirus infection, as Apostolov et al. suggest. Biological evidence of viral activity for the particles they found is needed to confirm this hypothesis. We stress this point because similar virus-like particles have been demonstrated in other conditions such as systemic lupus erythematosus, ${ }^{3}$ acute interstitial nephritis following ampicillin hypersensitivity, ${ }^{4}$ chronic pyelonephritis, ${ }^{5}$ amyloidosis, ${ }^{6}$ and diabetic nephropathy. ${ }^{7}$ This material might represent a product formed within the cell in response to cell injury. ${ }^{8}$

Klınika za Unutrašnje, Bolestı,

Radna Jedinica II

Nefrološko Odjeljenje,

71000 Sarajevo,

Momir Macanović DžEMal Rezakovic ENISA BASAGIC Yugoslavia NaIda BRKIC

1. Apostolov, K., Spasic, P., Bojanic, N. Lancet, 1975, 1i, 1271

2. Macanović, $M$, ibid. 1973, i, 720 .

3. Tisher, C. C., Kelso, H. B., Robınson, R. R., Gunnells, J. C., Burkholder, P. M. Ann. intern. Med. 1971, 75, 537.

4. Woodroffe, A. J., Weldon, M., Meadows, R., Lawrence, J. R. Med. F. Aust. $1975, \mathrm{i}, 65$.

5. Kawano, K., Miller, L., Kimmelstiel, P. New Engl. 7. Med. 1969, 281, 1228.

6. Hurd, E. R., Eigenbrodt, E., Ziff, M., Strunk, S. W. Arthritis Rheum. 1969, 12,541 .

7. Bloodworth, J. M. B., Shelp, W. D. Archs Path. 1970, 90, 252

8. Spargo, B. H. Hum. Path. 1975, 6, 405. 